Review

\title{
TOXIC EFFECTS OF NANOPARTICLES - DIFFERENCES AND SIMILARITIES WITH FINE PARTICLES
}

\author{
Žanna Martinsone and Mārīte Ārija Baḳe \\ Institute of Occupational Safety and Environmental Health, Rīga Stradiṇš University, Dzirciema iela 16, Rīga, LV-1007, LATVIA \\ E-mail: Zanna.Martinsone@rsu.Iv; Marite.Bake@rsu.Iv
}

Communicated by Andrejs Skaǵers

\begin{abstract}
There is increasing recognition that nanoparticles may pose a risk to human health. Toxicology studies have indicated that specific properties of nanoparticles drive their toxicity. These properties include surface area and chemistry, size and shape of particles, as well as charge and number, but to a lesser extent, mass. Nanoparticles can influence human health by occupational exposure and by environmental contacts. Uptake of nanoparticles may occur by inhalation, transdermal means and by ingestion. After inhalation, oral administration or parenteral administration, nanoparticles reach the lungs, gastrointestinal tract and brain. It is important to understand the similar and dissimilar features of nanoparticles and fine particles regarding impact on health. The general picture that emerges from experimental animal studies is that, on a mass dose basis, pulmonary toxicity is enhanced when particle size is reduced from the micrometre to the nanometre range. The increase in toxicity appears to be related to the increase in particle surface area. However, different existing materials in the nanometre size exhibit different degrees of toxicity on the respiratory tract. It is not possible to reach generic conclusions about toxicity based on consideration of size alone; the potential toxicity of each individual nanoparticulate material needs to be considered on a case-by-case basis. There is a clear lack of information on the potential health effects of nanoparticles produced for nanotechnologies. These uncertainties arise because of gaps in knowledge about the factors that are essential for predicting health risks - factors such as routes of exposure, translocation of materials once they enter the body, and interaction of the materials with the body's biological systems.
\end{abstract}

Key words: nanoparticles, toxicology, human health, exposure, toxicity, surface area, inflammation.

\section{INTRODUCTION: GENERAL QUESTIONS FOR COM- PARABLE ASSESSMENT OF TOXICITY AND HAZ- ARD PROPERTIES OF NANOPARTICLES}

Over the last decade, there has been increasing development of new manufactured nanomaterials. There is increasing recognition that nanoparticles may pose a risk to human health. Findings from the toxicology studies have indicated that specific properties of nanoparticles drive their toxicity. These properties include surface area and chemistry, size and shape of particles, as well as charge and number, but to a lesser extent, mass. Reference materials for manufactured nanoparticle toxicology studies have to be developed to carry out comparable assessment of nanoparticles with different properties.

The result of REFNANO (Reference materials for engineered nanoparticle toxicology and metrology) project was consensus (Table 1) reached between toxicology and metrology communities in the following outputs (www.iom-world.org/pubs/REFNANOReport.pdf):
- a rationale for the selection of priority reference/test materials (consideration of rationales from toxicological and metrological points of view and potential uses of reference materials led to proposal of three selection criteria: $\mathrm{A}-$ Industrial $=$ particles in high volume production, $\mathrm{ex}$ amples: $\mathrm{CB}, \mathrm{TiO}_{2}, \mathrm{CNT} ; \mathrm{B}-$ Hypothesis-testing $=$ particles possessing attributes that help understand mechanisms of toxicity, examples: long and short CNT, nanoand micro-sizes, coated and uncoated; C - Distributed analysis $=$ particles chosen as high and low toxicity standards or associated with well-established risks, examples: Ni, diesel exhaust particulate, alumina;

- a priority listing of reference/test materials to meet the needs of toxicology and metrology are given in Table 1 (highest priority nanomaterials after REFNANO evaluation are given in the table including valuable comments on key issues related to each particular material class);

- information related to the quantities of materials needed and the matrix in which they are present (for UK 100 lab- 
PRIORITY ONE CANDIDATE MATERIALS FOR TOXICOLOGY (Aitken et al., 2007)

\begin{tabular}{|c|c|c|}
\hline Material & Selection criteria & Comments \\
\hline Carbon black & $\mathrm{A}, \mathrm{B}, \mathrm{C}$ & $\begin{array}{l}\text { B - should be available in nano and micro-sizes; } \\
\mathrm{C} \text { - already well-studied in humans and animals, providing a good starting point. }\end{array}$ \\
\hline $\mathrm{TiO}_{2}$ & $\mathrm{~A}, \mathrm{~B}, \mathrm{C}$ & $\begin{array}{l}\text { B - should be available in nano and micro-sizes, and in coated and uncoated forms; } \\
\text { C - already well studied in humans and animals, providing a good starting point. }\end{array}$ \\
\hline $\mathrm{ZnO}$ & $\mathrm{A}, \mathrm{B}$ & B - should be available in coated and uncoated forms. \\
\hline
\end{tabular}

Polystyrene (Fluorescent)

Ag

Other key metals and metal oxides

Combustion derived NP
B

A

A (possibly B \& C) Priorities for ecotoxicology: $\mathrm{Zn}, \mathrm{Cu}, \mathrm{Ni}, \mathrm{Fe}$ and their oxides.

C To be used as a control particle since there is already a significant body of literature, risk and toxicology information available. oratories, the required quantities are $10 \mathrm{~kg}$ per material including human toxicology and ecotoxicology testing; preference for materials to be available as "dry powders", desirably — monodisperse, the only acceptable liquid would be ultra-pure water, but this would need to contain an antimicrobial preservative.);

- for materials considered as potential stable reference/test materials, the following minimum set of characterisation parameters was recommended (cited from REFNANO (Aitken et al., 2007) :

- aerodynamic equivalent diameter (as measured by electrical mobility or an equivalent technique);

- absolute length (in the case of high (>3:1) aspect ratio particles) (as measured by a length traceable (calibrated) microscopy);

- specific surface area, indicating the available reactive surface (as measured by an agreed isotherm method and traceable mass measurement);

- number of particles per unit mass (as measured either by a valid particle counting method or through validated indirect methods alongside a traceable mass measurement);

- concentration of bulk and/or surface contaminants/additives e.g. metals, soluble toxins (as measured by elemental analysis and a validated surface chemical analysis);

- polymorphic composition (as measured by a validated crystallographic analysis).

In addition to this minimum set of parameters, the following have also been identified as being desirable: shape; zeta potential; surface charge; solubility; hydrophobicity; agglomeration state.
The material can be reference material in terms of particle size and properties, and test material for toxicology. The property of interest of nanomaterials is clearly their toxicity, but it is not clear which toxicity parameter should be used as a reference and how it should be measured. The minimum dose set could include according to Warheit et al. (2007), the following criteria: substantial particle characterisation, pulmonary toxicity studies, acute dermal toxicity and sensitisation studies, acute oral and ocular studies, along with screening type genotoxicity, and aquatic studies.

It is recognised that complete and accurate particle characterisation is essential for understanding their potential toxicological properties. Furthermore, characterisation of nanomaterials is fundamental to ensure consistency and reproducibility of any tests (Anonymous, 2006a; Anonymous, 2006b; Powers et al., 2006; Aitken et al., 2007).

\section{CONFIRMATION OF THE DIFFERENCES IN TOXIC EFFECTS OF FINE PARTICLES AND NANOPARTI- CLES}

Nanoparticles can influence human health by occupational exposure and by environmental contact. Uptake of nanoparticles may occur by inhalation, transdermal means and by ingestion. The currently mostly investigated exposure route is via inhalation. After inhalation, oral administration or parenteral administration nanoparticles reach the lungs, gastrointestinal tract and brain. It is necessary to determine the similarities and dissimilarities in the impact on health of nanoparticles and fine particles. There are presumptive reviews evaluating research on toxicology of nanoparticles and fine particles (Anonymous, 2006a; Anonymous, 2006b; Borm et al., 2006; Donaldson et al., 2006; Nel et al., 2006; Anonymous, 2007; Mossman et al., 2007). The general picture that emerges from experimental animal studies is that, on a mass dose basis, pulmonary toxicity is enhanced when 
particle size is reduced from the micrometre to the nanometre range. The increase in toxicity appears to be related to the increase in particle surface area. However, different existing materials in the nanometre size range exhibit different degrees of toxicity towards the respiratory tract. It is not possible to reach generic conclusions about toxicity based on consideration of size alone; the potential toxicity of each individual nanoparticulate material needs to be considered on a case-by-case basis. The uptake and transport mechanisms in the lung and gastrointestinal tract differ from fine particles.

Overall, therefore, there is a clear lack of information on the potential health effects of nanoparticles produced for nanotechnologies. From the limited information that is available, the indications are that they might possess significant toxicity potential greater than fine particulates.

\section{POTENTIAL HEALTH CONCERNS}

There are many uncertainties as to whether the unique properties of engineered nanomaterials (which underpin their commercial potential) also pose occupational health risks. These uncertainties arise because of gaps in knowledge about the factors that are essential for predicting health risks - routes of exposure, translocation of materials once they enter the body, and interaction of the materials with the body's biological systems. The potential health risk following exposure to a substance is generally associated with the magnitude and duration of the exposure, the persistence of the material in the body, the inherent toxicity of the material, and the susceptibility or health status of the person. Results of existing studies in animals or humans on exposure and response to ultrafine or other respirable particles provide a basis for preliminary estimates of the possible adverse health effects from exposures to similar engineered materials on a nano-scale. The experimental studies in rodents and cell cultures have shown that the toxicity of ultrafine or nanoparticles is greater than that of the same mass of larger particles of similar chemical composition (Barlow et al. 2005; Nel et al., 2006; Mossman BT et al., 2007; Araujo et al., 2008). In addition to mass and particle surface area, other particle characteristics may influence the toxicity, including solubility, shape, and surface chemistry. More research is needed on the influence of particle properties on interactions with biological systems and the potential for adverse effects. International research strategies for evaluating the safety of nanomaterials are actively being developed through cooperative efforts (Anonymous, 2006a).

Existing toxicity information about a given material can also help to provide a baseline for anticipating the possible adverse health effects that may occur from exposure to that same material on a nano-scale.

\section{HEALTH EFFECT THROUGH INHALATION EXPO- SURE}

The most common route of exposure to airborne particles in the workplace is by inhalation. The deposition of discrete nanoparticles in the respiratory tract is determined by the particle's aerodynamic or thermodynamic diameter (depending on particle size). Agglomerates of nanoparticles will deposit according to the diameter of the agglomerate, not constituent nanoparticles. Research is still ongoing to determine the physical factors that contribute to the agglomeration and de-agglomeration of nanoparticles and the role of agglomerates in the toxicity of inhaled nanoparticles (Anonymous, 2006b; Donaldson et al., 2006).

For example, we know from studies in humans that a greater proportion of inhaled nanoparticles will deposit in the respiratory tract (both at rest and with exercise) compared to larger particles. We know from studies in animals that nanoparticles in the lungs can be translocated to other organs in the body, although it is not well known how this may be influenced by the chemical and physical properties of the nanoparticles (Takenaka et al., 2001; Kreyling et al., 2002; Oberdörster et al., 2004; Semmler et al., 2004). Due to their small size, nanoparticles can cross cell membranes and interact with subcellular structures such as mitochondria, where they have been shown to cause oxidative damage and impair function of cells in culture (Möller et al., 2002). Animal studies have shown that nanoparticles are more biologically active due to their greater surface area per mass compared with larger-sized particles of the same chemistry (Renwick et al., 2001; Barlow et al., 2005). While this increased biological activity of nanoparticles is a fundamental component to the utility of nanoparticles for industrial, commercial, and medical applications, the consequences of unintentional exposures of workers to nanoparticles are uncertain. Exposure to engineered nanoparticles is likely to cause adverse health effects similar to well-characterised ultrafine particles that have similar physical and chemical characteristics.

Studies in rodents and humans support the hypothesis that exposure to incidental ultrafine particles pose a greater respiratory hazard than the same mass of larger particles with a similar chemical composition. Studies of existing particles have shown adverse health effects in workers exposed to ultrafine particles (e.g., diesel exhaust particulate, welding fumes), and animal studies have shown that ultrafine particles are more inflammogenic and tumorigenic in the lungs of rats than an equal mass of larger particles of similar composition (Anonymous, 2006b; Nel et al., 2006; Mossman BT et al., 2007). If engineered nanoparticles have the same physiochemical characteristics that are associated with reported effects from ultrafine particles, they may also pose the same health concerns.

The biological mechanisms of particle-related lung diseases (e.g., oxidative stress, inflammation, and production of cytokines, chemokines, and cell growth factors) appear to be a consistent lung response for respirable particles including ultrafine or nanoparticles (Anonymous, 2006a).

Surface area and activity, and particle number, may be better predictors of potential hazard than mass. The greater potential hazard may be related to the greater number or 
surface area of nanoparticles compared with that for the same mass concentration of larger particles (Anonymous, 2006a; Nel et al., 2006). This hypothesis is based primarily on the pulmonary effects observed in studies of rodents exposed to various types of ultrafine or fine particles (e.g., titanium dioxide, carbon black, barium sulphate, diesel soot, coal fly ash, and toner) and in humans exposed to aerosols including nanoparticles (e.g., diesel exhaust and welding fumes). These studies indicate that for a given mass of particles, relatively insoluble nanoparticles are more toxic than larger particles of similar chemical composition and surface properties. The particles with less biologically reactive surfaces are less toxic (Anonymous, 2006). However, even particles with low inherent toxicity (e.g., titanium dioxide) have been shown to cause pulmonary inflammation, tissue damage, and fibrosis at sufficiently high particle surface area doses (Tran et al., 2000).

Through engineering, the properties of nanomaterials can be modified. In a recent study, Sayes et al. (2006) showed that the cytotoxicity of water-soluble fullerenes can be reduced by several orders of magnitude by modifying the structure of the fullerene molecules (e.g., by hydroxylation) viability. Increasing the sidewall functionalization of single-walled carbon nanotubes (SWCNT) also rendered these nanomaterials less cytotoxic to cells in culture (Sayes et al., 2006). Differences in the phase composition of nanocrystalline structures can influence their cytotoxicity; in a recent study comparing two types of titanium dioxide nanoparticles, anatase was more cytotoxic and produced more reactive species than did rutile, which has similar specific surface area (Sayes et al., 2006). Reactive oxygen speies were also associated with the cytotoxicity of titanium dioxide nanoparticles to mouse microganglia (brain cells) grown in culture (Anonymous, 2006b).

The studies of ultrafine particles may provide useful data to develop preliminary hazard or risk assessments and to generate hypotheses for further testing viability. The data generated by Faux et al. (2003) demonstrate a relationship between the surface area dose and inflammatory response in vitro with a range of poorly soluble particles, as previously shown in vivo. This discovery has important practical and theoretical implications. At the theoretical level, it has highlighted the role of the epithelial cells in the proximal alveolar region, their interaction with the deposited particles and the ensuing molecular events leading to inflammation. At the practical level, it has offered a new approach to interpreting in vitro data, a cost effective way of screening new materials for toxicity and an alternative way to animal testing. But particles also exist in a wide range of surface reactivity. Upon deposition in the pulmonary region, such reactivity exerts an oxidative stress on the cells via contact between particle/cell surface areas. Consequently, both highly reactive particles with a low surface area and low toxicity particles with a high surface area can exert the same oxidative stress level on the cells they come into contact with. When this inhaled dose reaches a critical level, an inflammatory response occurs. For low toxicity dusts, inflam- mation will diminish with the cessation of exposure, while for high toxicity dusts, inflammation will persist (Tran et al., 2000). Persistent inflammation is likely to lead to diseases such as fibrosis and cancer. Thus, it is important to control inflammation. The small-diameter nanoparticles are capable of penetrating epithelial cells, entering the bloodstream from the lungs (Gilmour et al., 2004), and even translocating to the brain via the olfactory nerves (Oberdorster et al., 2004). Carbon nanoparticles (Oberdorster et al., 2004) and manganese oxide (30 nm) (Elder et al., 2006) can accumulate in the olfactory bulb following inhalation, and the manganese nanoparticles induce inflammatory changes in the brain (Feikert et al., 2004). The authors argue that despite the differences between human and rodent nasal anatomy, these results are relevant to human nanoparticle exposures.

\section{MECHANISTIC BASIS FOR LOCAL TOXICITY TO THE LUNG}

The importance of particle surface area in the toxicity of inhaled poorly soluble particles has been clearly established. However, although various hypotheses have been developed and tested to elucidate the mechanistic basis for the influence of particle surface area on toxicity, many gaps in knowledge remain (Anonimous, 2004). The information presented shows that, for the same material, smaller particles elicit a greater pulmonary inflammatory response than do larger particles, on a mass basis. In addition, it has been shown that particle surface area can provide a unifying dose metric for a range of different insoluble particles of low cytotoxicity; regardless of the particle type, toxicity to the respiratory tract (in terms of rat lung tumour response) is related to particle surface area (Anonymous, 2004).

However, two other factors have been proposed to be involved in determining the respiratory tract response to particle exposure:

- particle surface activity - specifically, the ability of the particle surface to generate free radicals;

- particle agglomeration/disagglomeration - a determinant of the availability of individual particles to the lung surface once the material has entered the lung (Borm et al., 2006).

These factors may well be related to particle surface area, but they are also particle specific and may be an important determinant of inherent toxicity towards the respiratory tract.

\section{HEALTH EFFECTS THROUGH INGESTION EXPO- SURE}

The nanoparticles cleared by macrophages, via the mucociliary escalator, can be swallowed and therefore available for transfer to other body organs via the gastro-intestinal compartment. There is also some evidence that 
smaller particles can be transferred across the intestinal wall more readily than their larger counterparts (Behrens et al., 2002). Little is currently known about the health effects of nanoparticles on the liver and kidneys, as well as regarding the correct metric for describing the nanoparticle dose in these organs. Another area that merits further research is the transfer of nanoparticles across the placenta barrier. Exposure to nanoparticles during the critical window of foetal development may lead to developmental damage in the offspring.

Nanoparticles can be ingested directly in food, water, cosmetics, or drugs. Although nanoparticles in food are infrequently taken up into gut lymphatic and distributed to other organs, most nanoparticles are rapidly eliminated via faces (Nel et al., 2006).

\section{HEALTH EFFECT THROUGH DERMAL EXPOSURE}

Some studies suggest that nanoparticles also could enter the body through the skin during occupational exposure. The recent studies indicate that nanoparticles of titanium dioxide $\left(\mathrm{TiO}_{2}\right)$ used in sunscreens do not penetrate beyond the epidermis. However, the report also makes a number of recommendations addressing the need for further and more transparent information in the area of nanoparticle dermal penetration. Studies have shown that particles smaller than $1 \mu \mathrm{m}$ in diameter may penetrate into mechanically flexed skin samples (Anonymous, 2004; Borm et al., 2006).

\section{SPECIFIC TOXICITY OF DIFFERENT KIND OF NANO- PARTICLES}

Carbon black industry. Carbon black is an amorphous carbon composed of particles and fused aggregates. Particle size, surface area, average aggregate mass distributions, morphology or structure, and chemical composition, differentiate the various grades of carbon black. Primary particles fuse in the manufacturing process to form aggregates. Aggregates typically cluster into agglomerates. The airborne particles found in carbon black manufacturing plants are not individual aggregates, but agglomerates of many carbon black aggregates. It was concluded that no ultrafine $(<100$ $\mathrm{nm})$ and very few fine $(<1000 \mathrm{~nm})$ particles were to be found at carbon black manufacturing sites (Anonymous, 2006b).

Researchers of the nanotoxicology field are particularly concerned about the potential for carbon nanotubes (CNTs) to cause health effects since they have both nanosize and fibre properties (Kuhlbusch et al., 2001; Donaldson et al., 2006). These studies have shown that the toxicity of CNT may differ from that of other nanoparticles of similar chemical composition. For example, single-walled CNTs (SWCNT) have been shown to produce adverse effects including granulomas in the lungs of mice and rats, at mass doses at which ultrafine carbon black did not produce these adverse effects (Shvedova et al., 2003; Anonymous, 2006b).
The SWCNTs (impure, containing 30\% iron, no details of size of tubes) have been observed to induce oxidative stress in human keratinocytes grown in vitro; this was an extensive study in that a broad range of endpoints were used to demonstrate induction of oxidative stress, including production of free radicals by electron spin resonance, and depletion of cellular antioxidants and vitamin E. They also showed that the CNTs dose-dependently induced cell death, and altered the morphology of the cells (Shvedova et al., 2003).

The four reports that have considered epithelial cells have used either the human bronchial epithelial cell line BEAS2B or the human kidney cell line HEK293, and shown that SWCNTs induce oxidative stress and toxicity (Svedova et al., 2003), and modulate gene expression (Cui et al., 2005; Kagan et al., 2006).

Of the studies carried out in macrophage and monocyte cells, both SWCNTs and multi-walled CNTs (MWCNTs) were reported to be cytotoxic in murine macrophages (Murr et al., 2005), and the toxicity of different particles was ranked in alveolar macrophages: SWCNT > MWCNT > quartz > C60 fullerene (Jia et al., 2005). The authors of the latter study demonstrated that monocytic cell phagocytic ability was reduced after exposure to all of the nanotubes tested. Microscopic examination of the cells after treatment with the nanotubes showed "frustrated phagocytosis". The frustrated phagocytosis suggests that clearance of nanotubes from the lungs by macrophages may be impaired (Brown et al., 2007).

Both CNTs (20-40nm wide and 220 or $825 \mathrm{~nm}$ long) induced TNF $\alpha$ dose-dependently in human THP-1 cells, although at a lower level than a microbial lipopeptide. The cellular response (inflammation and engulfment by macrophages) is affected by CNT length, and resultant morphology of the nanotubes (Sato et al., 2005).

Titanium dioxide $\left(\mathrm{TiO}_{2}\right)$. Titanium dioxide is widely used in a variety of products. Ultrafine $\mathrm{TiO}_{2}$ powders are used in cosmetics, pigments, toner, coating material etc. Titanium dioxide $\left(\mathrm{TiO}_{2}\right)$ is manufactured worldwide in large quantities for use in a wide range of applications and it has generally been considered to be toxicologically inert. However, a number of studies have reported lung tumours in rats (not hamsters or mice) after a lifetime of exposure to very high concentrations of pigment grade $\mathrm{TiO}_{2}$. Rat may be oversensitive to high lung burdens of pigment grade and ultrafine $\mathrm{TiO}_{2}$ compared with mice or hamsters, and therefore, there appears to be no clear link between human occupational exposure to $\mathrm{TiO}_{2}$ and lung cancer risk (Hext et al., 2005). Warheit et al. (2007) report the in vivo pulmonary toxicity results of a set of new developed, well-characterised, ultrafine $\mathrm{TiO}_{2}$ particle types and demonstrated low inflammatory potential and lung tissue toxicity. Acute dermal irritation studies in rabbits and local lymph node assay results in mice indicated that $\mathrm{TiO}_{2}$ was not a skin irritant or dermal sensitiser. Acute oral toxicity demonstrated very low toxicity. Genotoxicity tests demonstrated that $\mathrm{TiO}_{2}$ was negative 
in both the bacterial reverse mutation test and in an in vivo mammalian chromosome aberration test with Chinese hamster ovary cells.

Metals (alumina powder, silver, gold, copper, manganese, fine zinc oxide particles). Alumina powder can also be produced using flame aerosol reactors and is used for production of integrated circuit substrates, high pressure sodium-vapour lamps, catalyst supports, cutting tools, heat and wear-resistant materials and as shielding material in radioactive systems. It is also finding new applications in the preparation of high temperature filters, coatings and membrane supports suitable for liquid or gas separations (Anonymous, 2006a).

The acute toxic effects of five different metal/metal oxide nanoparticles were assessed in a rat liver cell line (BRL3A). Silver nanoparticles were highly toxic; molybdenum nanoparticles were moderately toxic, and iron oxide, aluminum, and manganese nanoparticles showed no toxicity at the doses tested, although at high doses, the cells became irregular in shape. The authors propose that cell death induced by silver was likely mediated by oxidative stress (Hussain et al., 2005).

The metal nanoparticles were tested in a monodisperse aerosol form on epithelial cells; copper was the most potent at inducing cytokine IL-8, but the kinetics of induction were different compared with nickel or vanadium, and IL-8 production was increased markedly by acidification of the particles, potentially via oxidative stress. The authors considered that this study showed the complexity of cellular responses to nanoparticles (Anonymous, 2006b).

Functionalisation of gold nanoparticles with cationic side chains (but not anionic side chains) increases cytotoxicity at high doses (although the cell type was not specified) (Goodman et al., 2004).

Finally, the only in vitro study using a neuronal cell line reported that nano-sized manganese oxide nanoparticles (40 $\mathrm{nm}$ ) dose-dependently induce depletion of metabolites of the neurotransmitter dopamine in PC12 cells, in contrast to silver nanoparticles (Hussain et al., 2006).

Zinc is generated in large quantities by industrial processes such as welding or cutting galvanised steel. Freshly generated zinc oxide can cause an inflammatory response known as fume fever (Beckett et al., 2005).

Nickel powder. Ultrafine nickel $(20 \mathrm{~nm})$ has a number of industrial applications. The present occupational exposure limits are based on mass, and do not distinguish between particles of different sizes. Ultrafine nickel is much more toxic to the rat lung than standard nickel, and authors offer a hypothesis that the mechanism arises from the nanoparticles' greater surface area, and ability to induce free radicals, TNF $\alpha$ and nitric oxide (Dick et al., 2003).

Different particles, instilled on an equal mass basis (cobalt $(20 \mathrm{~nm})$, titanium dioxide $(20 \mathrm{~nm})$, nickel $(20 \mathrm{~nm})$, all three of which have the same surface area, and carbon black (14 $\mathrm{nm}$ ), which has a surface area five to six times greater), induced different amounts of inflammation and lung injury after intratracheal instillation according to markers of inflammation and epithelial damage assessed in BAL (bronchi alveolar lavage). The effects seemed to correlate with the ability of the nanoparticles to generate free radicals and oxidative damage, and hence with their surface reactivity rather than size or surface area, although other factors must also play a part, since Ni induced formation of free radicals but was less pro-inflammatory than Co or carbon black (Dick et al., 2003).

Fumed silica (silicon dioxide). The synthesis of fumed silica ceramic powders is carried out using flame aerosol reactors. Fumed silica is one of the produced major chemical products of industrial importance. Fumed silica is used in optical fibres, filler in silicone rubber, thickening, antisettling and reinforcing agents, catalyst carriers, and in polishing material in microelectronics (Anonymous, 2006b).

Polytetrafluoroethylene (PTFE) fume. Early studies with PTFE (polytetrafluoroethylene) particles around $20 \mathrm{~nm}$ in diameter showed that airborne concentrations of a supposedly inert insoluble material lower than $50 \mu \mathrm{g} / \mathrm{m}^{3}$ could be fatal to rats (Johnston et al., 2000). Since then, many studies have indicated that the toxicity of insoluble materials increases with decreasing particle size, on a mass for mass basis (Faux et al., 2003).

\section{RESEARCH STRATEGIES FOR SAFETY EVALUA- TION OF NANOMATERIALS ACCORDING TO A RE- VIEW OF LITERATURE}

Complete toxicological characterisation of nanoparticles should include the measurement of:

- Particle size distribution (in terms of number, volume and surface area) and shape information of the powder "as received", of the material "as-dosed" or "as-exposed" and at the point of interaction with the organism.

- State of dispersion and changes in particle size distribution to that of a fully dispersed system; state of dispersion or agglomerate size of the particles in the biological environment.

- Physical and chemical properties (including elemental composition, density, crystal structure, chemical reactivity, solubility, conductivity, melting point, hardness, optical properties) of the powder "as received" and of the particles in the biological environment.

- Surface area and porosity of the powder "as received", of the particles "as dosed" and in the biological environment (these properties can change as a result of bimolecular adsorption or agglomeration).

- Surface chemistry (such as surface composition and structure, surface energy/wet ability, surface charge, surface 
reactivity or zeta potential, presence and chemical nature of the adsorbed species) of the powder "as received" and as close to the physiological conditions as practical (Anonymous, 2006b).

The conclusions are:

1. The minimum toxicity parameter dose set should include the following criteria for evaluation toxicity of nanoparticles: substantial particle characterisation, pulmonary toxicity studies, acute dermal toxicity and sensitisation studies, acute oral and ocular studies, along with screening type genotoxicity, and aquatic studies.

2. From the limited information that is available, it happens that nanoparticles might possess significant toxicity potential greater than fine particulates; the increase in toxicity appears to be related to increase in particle surface area, and pulmonary toxicity is enhanced when particle size is reduced from the micrometre to nanometre range.

3. Due to their small size, nanoparticles can cross cell membranes and interact with subcellular structures such as mitochondria, where they have been shown to cause oxidative damage and impair function of cells in culture. The nanoparticles are more biologically active due to their greater surface area per mass compared with larger-sized particles of the same chemistry.

4. The most common route of exposure to airborne particles in the workplace is by inhalation. The small diameter of nanoparticles enables their penetration into epithelial cells, entering the bloodstream from the lungs and even translocating to the brain via the olfactory nerves. Nanoparticles can accumulate in the olfactory bulb following inhalation and can induce inflammatory changes in the brain.

5. The type of surface coating and differences in the phase composition of nanocrystalline structures can influence their cytotoxicity and have a significant effect on cell motility and viability. The structural modifications reduce the cytotoxicity by reducing the generation of oxygen radicals, which is a probable mechanism of cell membrane damage and death.

6. Health effects of nanoparticles through ingestion exposure inquire broader research; there is some evidence that smaller particles can be transferred more readily than their larger counterparts across the intestinal wall. Further research is needed on transfer of nanoparticles across the placenta barrier and the possible impact of foetal development.

7. The dermal absorption and skin penetration of nanoparticles needs a better evaluation because few and contradictory data are present in the literature, mainly on titanium dioxide used in sunscreen cosmetics.

8. The toxicity of nanoparticles depends from chemical composition and morphology or structure of materials.
Carbon nanotubes produce adverse effects including granulomas in the lungs of mice and rats at mass doses at which ultrafine carbon black did not produce these adverse effects since they have both nanosize and fibre properties. Titanium dioxide has generally been considered to be toxicologically inert. The ultrafine nickel nanoparticles are much more toxic than standard nickel. Zinc/zinc oxide nanoparticles generated in the industrial welding processes can cause inflammatory response known as fume fever.

9. The workplace represents a critical interface between people and nanotechnology, and an area where potential impact needs to be understood and managed. In the future, it is also likely that even wider distribution of these particles may have significant effects on organisms.

\section{ACKNOWLEDGEMENTS}

This work was supported by the European Community under the "Structuring the European Research Area" $6^{\text {th }}$ Framework Programme project IMPART NMP4-CT-2005013968 "Improving understanding of the impact of nanoparticles on human health and environment".

\section{REFERENCES}

Aitken, R.J., Dankinm S.M., Tranm C.L., Donaldson, K., Stone V., Cumpson, P., Johnstone, J., Chaudhry, Q., Cash, S. (2007). REFNANO: Reference Materials for Engineered Nanoparticle Toxicology and Metrology. IOM, Final Report on Project CB01099: 30 pp www.iom-world.org/pubs/REFNANOReport.pdf.

Anonymous (2004). Health and Safety Executive (HSE) Hazard assessment toxicity. Health effects of particles produced for nanotechnologies. Document EH75/6.

Anonymous (2006a). Health and Safety Executive (HSE) NanoAlert Service, Issue 1. www.hse.gov.uk/horizons/nanotech/nanoalert001.pdf.

Anonymous (2006b). NIOSH - National Institute for Occupational Safety and Health Approaches to safe nanotechnology: An information exchange with NIOSH. Draft for public comment, CDC Workplace Safety and Health. Washington.

Anonymous (2007). Health and Safety Executive (HSE) NanoAlert Service, Issue 2. www.hse.gov.uk/horizons/nanotech/nanoalert002.pdf.

Araujo, J.A., Barajas, B., Kleinman, M., Wang, X., Bennet, B.J., Gong, K.W., Navab, M., Harkema, J., Sioutas, C., Lusis, A.J., Nel, A.E. (2008). Ambient particulate pollutants in the ultrafine range promote early atherosclerosis and systemic oxidative stress. Circ. Res., 102, 589-596.

Barlow, P.G., Clouter Baker, A., Donaldson, K., McCollum, J., Stone, V. (2005). Carbon black nanoparticles induce type II epithelial cells to release chemotoxins for alveolar macrophages. Particle Fibre Toxicol., 2, 11.

Beckett, W.S., Chalupa, D.F., Pauly-Brown, A., Speers, D.M., Stewart, J.C., Frampton, M.W., Utell, M.J., Huang, L.-S., Cox, C., Zareba,W., Oberdoerster, G. (2005). Comparing inhaled ultrafine versus fine zinc oxide particles in healthy adults: A human inhalation study. Amer. J. Respir. Crit. Care. Med., 171(10), 1129-1135.

Behrens, I., Pena, A.I., Alonso, M.J., Kissel, T. (2002). Comparative uptake studies of bioadhesive and non-bioadhesive nanoparticles in human intestinal cell lines and rats: The effect of mucus on particle adsorption and transport. Pharm. Res., 19(8), 1185-1193.

Borm, P.J.A., Robbins, D., Haubold, S., Kuhlbusch, T., Fissan, H., Donaldson, K., Shins, R., Stone, V., Kreyling, W., Lademann, J., Krutman, J., Warheit, D., Oberdorster, E. (2006). The potential risks of nano- 
materials: Review carried out for ECETOX. Particle Fibre Toxicol., 3, 11. http://www.particleandfibretoxicology.com/content/3/1/11.

Brown, D.M., Kinloch, I.A., Bangert, U., Windle, A.H., Walter, D.M., Walker, G.S., Scotchford, C.A., Donaldson, K. and Stone, V. (2007). An in vitro study of the potential of carbon nanotubes and nanofibres to induce inflammatory mediators and frustrated phagocytosis. Carbon, 48(9), 1743-1756.

Cui, D., Tian, F., Ozkan, C.S, Wang, M., Gao, H. (2005). Effect of single wall carbon nanotubes on human HEK293 cells. Toxicol. Lett., 155(1), 73-85.

Dick, C.A.J., Brown, D.M., Donaldson, K. and Stone, V. (2003). The role of free radicals in the toxic and inflammatory effects of four different ultrafine particle types. Inhalation Toxicol., 15(1), 39-52.

Donaldson, K., Aitken, R., Tran, L., Stone, V., Duffin, R., Forrest, G., Alexander, A. (2006). Carbon nanotubes: A review of their properties in relation to pulmonary toxicology and workplace safety. Tox. Sci., 92(1), 5-22.

Elder, A, Gelein, R., Silva, V., Feikert, T., Opanashuk, L., Carter, J., Potter, R., Maynard, A., Ito, Y., Finkelstein, J., Oberdorster, G. (2006). Translocation of inhaled ultrafine manganese oxide particles to the central nervous system. Environ. Health Perspect., 114(8), 1172-1178.

Faux, S.P., Tran, C.L., Miller, B.G., Jones, A.D., Monteiller, C., Donaldson, K. (2003). In vitro determinants of particulate toxicity: The dose metric for poorly soluble dusts. HSE Research Report, 154.

Feikert, T., Mercer, P., Corson, N., Gelein, R., Opanashuk, L., Elder, A., Silva, V., Carter, J., Maynard, A., Finkelstein, J., Oberdorster, G. (2004). Inhaled solid ultrafine particles (UFP) are efficiently translocated via neuronal nasal-olfactory pathways. Toxicologist, 78 (Suppl. 1), 435-436.

Gilmour, P.S., Ziesenis, A., Morrison, E.R., Vickers, M.A., Drost, E.M., Ford, I., Karg E., Mossa, C., Schroeppel, A., Ferron, G.A., Heyder, J., Greaves, M., MacNee, W., Donaldson, K. (2004). Pulmonary and systemic effects of short-term inhalation exposure to ultrafine carbon black particles. Toxicol. Appl. Pharmacol., 195, 35-44.

Goodman, C.M., McCusker, C.D., Yilmaz, T., Rotello, V.M. (2004). Toxicity of gold nanoparticles functionalized with cationic and anionic side chains. Bioconjugate Chem., 15(4), 897-900.

Hext, P.M., Tomenson, J.A. and Thompson, P. (2005). Titanium dioxide: Inhalation toxicology and epidemiology. Ann. Occup. Hygiene, 49(6), $461-472$

Hussain, S.M., Hess, K.L., Gearhart, J.M., Geiss, K.T., Schlager, J.J. (2005). In vitro toxicity of nanoparticles in BRL $3 \mathrm{~A}$ rat liver cells. Toxicol. in vitro, 19(7), 975-983.

Hussain, S.M., Javorina, A.K., Schrand, A.M., Duhart, H.M., Ali, S.F., Schlager, J.J. (2006). The interaction of manganese nanoparticles with PC-12 cells induces dopamine depletion. Toxicol. Sci., 92(2), 456-463.

Jia, G., Wang, H., Yan, L., Wang, X., Pei, R., Yan, T., Zhao, Y., Guo, X. (2005). Cytotoxicity of carbon nanomaterials: Single-wall nanotube, multi- wall nanotube, and fullerene. Environ. Sci. Technol., 39(5), $378-1383$.

Johnston, C.J., Finkelstein, J.N., Mercer, P., Corson, N., Gelein, R., Oberdorster, G. (2000). Pulmonary effects induced by ultrafine PTFE particles. Toxicol. Appl. Pharmacol., 168(3), 208-15.

Kagan, V., Potapovich, A., Osipov, A., Schwegler, B.D., Kisin, E., Mercer, R., Castranova, V., Shvedova, A. (2006). Iron-rich single walled carbon nanotubes are effective catalysts of oxidative stress in RAW 264.7 macrophage cell culture model: Interactions with inflammatory response and in vivo implications. Toxicol. Lett., 165(1), 88-100.

Kreyling, W.G., Semmler, M., Erbe, F., Mayer, P., Takenaka, S., Schulz, H. (2002). Translocation of ultrafine insoluble iridium particles from lung epithelium to extrapulmonary organs is size dependent but very low. $J$. Toxicol. Environ. Health, 65, 1513-1530.

Kuhlbusch, T., Neumann, S., Ewald, M., Hufmann, H., Fissan, H. (2001). Final report on characterisation of fine airborne particles at carbon black

Received 12 May 2009 working places in industry. Final report to the Scientific Advisory Group of the International Carbon Black Association.

Moller, W., Hofer, T., Ziesenis, A., Karg, E., Heyder, J. (2002). Ultrafine particles cause cytoskeletal dysfunctions in macrophages. Toxicol. Appl. Pharmacol., 182(3), 197-207.

Mossman, B.T., Borm, P.J., Castranova, V., Cost, D.L., Donaldson, K., Kleeberger, R. (2007). Mechanisms of action of inhaled fibers, particles and nanoparticles in lung and cardiovascular disease. Particle and Fibre Toxicology 4, 4 .

http://www.particlesandfibretoxicology.com/content/4/1/4

Murr, L.E., Garza, K.M., Soto, K.F., Carrasco, A., Powell, T.G., Ramirez, D.A., Guerrero, P.A., Lopez, D.A. and Venzor, I.J. (2005). Cytotoxicity assessment of some carbon nanotubes and related carbon nanoparticle aggregates and the implications for anthropogenic carbon nanotube aggregates in the environment. Int. J. Environm.Res. Public Health, 2(1), 31-42.

Nel, A., Xia, T. Maedler. L., Li, N. (2006). Toxic potentials of materials at the Nanolevel. Science, 311, 622-627.

Oberdorster, G., Sharp, Z., Atudorei, V., Elder, A., Gelein, R., Kreyling, W. , Cox, C. (2004) . Translocation of inhaled ultrafine particles to the brain. Inhalation Toxicol., 16(6/7), 437-445.

Powers, K.W., Brown, S.C., Krishna,V.B., Wasdo, S.C., Moudgil, B.M., Roberts, S.M. (2006). Research strategies for safety evaluation of nanomaterials. Part VI. Characterization of nanoscale particles for toxicological evaluation. Toxicol. Sci., 90, 296-303.

Renwick, L.C., Donaldson, K., Clouter, A. (2001). Impairment of alveolar macrophage phagocytosis by ultrafine particles. Toxicol. Appl. Pharmacol., 172(2), 119-127.

Sato, Y., Yokoyama, A., Shibata Ken, I., Akimoto, Y., Ogino Shin, I., Nodasaka, Y., Kohgo, T., Tamura, K., Akasaka, T., Uo, M., Motomiya, K., Jeyadevan, B., Ishiguro, M., Hatakeyama, R., Watari, F., Tohji, K. (2005). Influence of length on cytotoxicity of multi-walled carbon nanotubes against human acute monocytic leukemia cell line THP-1 in vitro and subcutaneous tissue of rats in vivo. Mol. Bio Syst., 1(2), 176-182.

Sayes, C.M., Liang, F., Hudson, J.L., Mendez, J., Guo, W., Beach, J.M., Moore, V.C., Doyle, C.D., West, J.L., Billups, W.E., Ausman, K.D., Colvin, V.L. (2006) Functionalization density dependence of single-walled carbon nanotubes cytotoxicity in vitro. Toxicol Lett., 161(2), 135-142.

Semmler, M., Seitz, J., Erbe, F., Mayer, P., Heyder, J., Oberdorster, G., Kreyling. W.G. (2004). Long-term clearance kinetics of inhaled ultrafine insoluble iridium particles from the rat lung, including transient translocation into secondary organs. Inhal. Toxicol., 16(6/7), 453-459.

Shvedova, A., Castranova, V., Kisin, E.R., Schwegler Berry, D., Murray, A.R., Gandelsman, V.Z., Maynard, A., Baron, P. (2003). Exposure to carbon nanotube material: Assessment of nanotube cytotoxicity using human keratinocyte cells. J. Toxicol. Environ. Health. Part A, 66(20), 1909-1926

Shvedova, A., Kisin, E., Murray, A., Schwegler Berry, D., Gandelsman, V., Baron, P., Maynard, A., Gunther, M. and Castranova, V. (2003). Exposure of human bronchial epithelial cells to carbon nanotubes caused oxidative stress and cytotoxicity. In: Meeting of the Society for Free Radical Research, European Section, Free Radicals and Oxidative Stress: Chemistry, Biochemistry and Pathophysiological Implications (pp. 91-103). Ioannina: Society for Free Radical Research.

Takenaka, S., Karg, E., Roth, C., Schulz, H., Ziesenis, A., Heinzmann, U., Schramel, P., Heyder, J. (2001). Pulmonary and systemic distribution of inhaled ultrafine silver particles in rats. Environ. Health Perspect., 109(Suppl 4), 547-551.

Tran, C.L., Buchanan, D., Cullen, R.T., Searl. A., Jones, A.D., Donaldson, K. (2000). Inhalation of poorly soluble particles II. Influence of particle surface area on inflammation and clearance. Inhal. Toxicol., 12, 1113-1126.

Warheit, B., Hoke, R.A., Finlay, C., Donner, M., Reed, K.L., Saues, K. (2007). Development of a base set of toxicity tests using ultrafine $\mathrm{TiO}_{2}$ particles as a component of nanoparticle risk management. Toxicol. Lett., 171(3), 99-110. 


\section{NANODAL̦IṆU TOKSISKIE EFEKTI - ATŠK̦IRĪGAIS UN LĪDZĪGAIS AR MIKRODAḶIṆĀM}

Toksikoloğiskie pētījumi parāda, ka nanodaḷiņām piemīt specifiskas īpašības, kas ietekmē to toksicitāti. Iedarbības raksturs saistīts ar daḷiņu virsmas laukumu, veidu un ķīmisko dabu, kā arī ar dạiņu skaitu un lādiņu, bet mazāk - ar to masu. Nanodalịnas var nonākt organismā, tās ieelpojot (darbā un apkārtējā vidē), caur ādu un norijot. Izpētītākais daļiņu uzņemšanas veids ir inhalācija. Eksperimentālos pētījumos novērots toksicitātes pieaugums, samazinoties daḷiņu izmēriem līdz nanometru skalai, kas, domājams, ir saistīts ar ievērojamo virsmas laukuma palielinājumu. Eksistējošām nanodalininām ir novērota dažāda respiratorā toksicitāte, tādēḷ nav iespējams vispārinājums par nanodalinu toksicitāti, pamatojoties tikai uz to izmēru. Pētījumi rāda, ka pašreiz vēl ir nepietiekama zinātniski pamatota informācija par nanodaḷiņu iedarbības risku veselībai, un svarīgi ir apzināt visus ietekmējošos faktorus, kas ir būtiski, lai varētu noteikt nanodaḷiņu mijiedarbību ar organisma bioloğiskām sistēmām. 